\title{
Pharmacological management of cancer pain in children
}

\author{
Sebastiano Mercadante ${ }^{a, b, *}$, Antonello Giarratano ${ }^{a, b}$ \\ a Anesthesia \& Intensive Care and Pain Relief \& Supportive Care Unit, La Maddalena Cancer Center, Italy \\ ${ }^{\mathrm{b}}$ Chair of Anesthesiology, University of Palermo, Italy
}

Accepted 14 January 2014

\section{Contents}

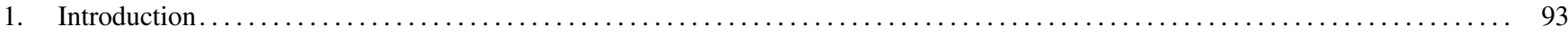

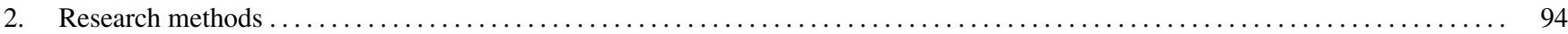

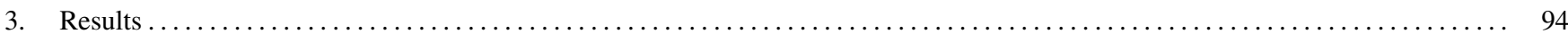

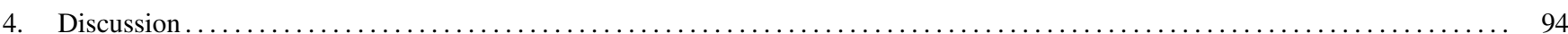

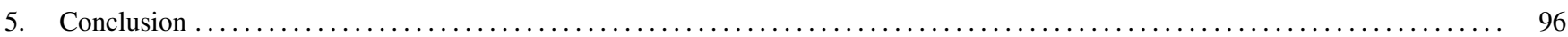

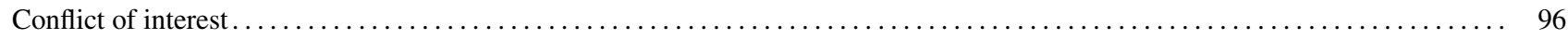

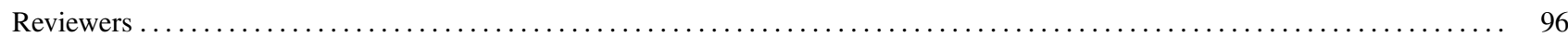

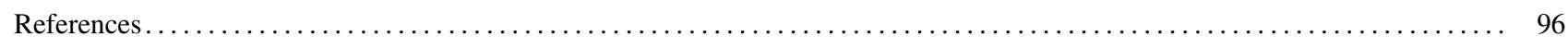

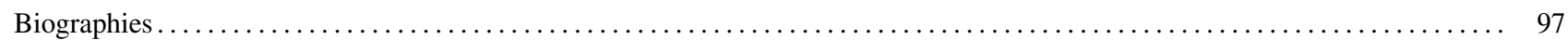

\begin{abstract}
The aim of this review was to assess cancer pain management in children on the basis of research published in the last ten years. Nine were papers providing clinical data, with a minimum of ten patients. No controlled studies were found. Regardless of general principles and existing recommendations, clinical data should confirm the applicability of this concept. The trials published in the last years did not provide further information to improve cancer pain management in children, because of the experience and the low number of drugs used, reflecting only meaningful opinions of experts in the field. The amount and the quality of data still remain poor, as only 737 subjects (about 80 patients per year) were surveyed with open-label designs or retrospective analysis. No comparison among possible treatments or drugs has ever been performed. Most of these trials are short-lived and assessment of adverse effects is often problematic. The experience with opioids is quite limited, and adjuvants have been seldom assessed, unless for case reports which have not been considered in this analysis. The management of breakthrough pain has never been specifically evaluated.

Further clinical trials are needed to evaluate dose equivalence, clinical efficacy and safety of opioid analgesics, differences in opioid response, adjuvants and other drugs commonly used to manage opioid-related adverse effects, and dose strengths necessary for most children. (C) 2014 Elsevier Ireland Ltd. All rights reserved.
\end{abstract}

Keywords: Cancer pain; Children; Pediatrics; Opioids

\section{Introduction}

Pain in a child with cancer poses significant challenges for health professionals. Pain is the most common discomfort

\footnotetext{
* Corresponding author at: Anesthesia \& Intensive Care and Pain Relief \& Supportive Care Unit, La Maddalena Cancer Center, Via San Lorenzo 312, 90146 Palermo, Italy. Tel.: +39 0916806521; fax: +39 0916806110.

E-mail addresses: terapiadeldolore@lamaddalenanet.it, 03sebelle@gmail.com (S. Mercadante).
}

experienced by children with cancer and occurs in almost $89 \%$ of patients in an advanced stage of the disease. It is most often not adequately treated because of inexperience and unfounded fears of analgesic treatment [1]. About ten years ago an analysis of scientific literature regarding cancer pain management in children evidenced that existing data were limited and that most recommendations were substantially provided on the basis of anecdotal experience translated by studies in adults [2]. The aim of this review was to assess cancer pain management in children on the basis of research 
published in the subsequent years to appreciate whether more consistent data have been produced to provide more robust data in this population.

\section{Research methods}

A systematic search of the existing literature from 2004 to December 2013 was performed via electronic database PubMed (http://www.ncbi.nlm.nih.gov) (filter 10 years). The terms were "cancer pain" AND "children" OR "pediatrics". References contained in the article finally selected were reviewed as to the possibility of finding any additional papers of interest. Browsers of pediatric journals were also assessed. For those articles in which the title and/or abstract were not available or were insufficient to clarify the content of the article, the article was read in its entirety to make the decision over its content by the two authors. To be included in this systematic review, papers had to be full text clinical reports studying the pharmacological management of cancer pain in children and published in English language. All clinical study designs were eligible, but case-series with less than 10 patients were not considered. Papers assessing procedural pain and treatment-induced pain were excluded. Non-clinical reports such as reviews were also excluded.

\section{Results}

The initial search resulted in 61 hits. Title, abstracts or when necessary the full text paper were screened for inclusion. Eight papers met the inclusion criteria. Other five papers were found after checking cross-references or consulting the principal journals of the field (pediatrics, pain, and palliative care). Globally 13 papers in the period taken into consideration provided new clinical data with a minimum of ten patients.

No controlled studies were found. Details of the clinical papers examined are shown in Table 1. Globally, 935 children were surveyed. In six studies [3-8], 706 subjects were treated according the WHO ladder, most of them successfully, with limited and acceptable adverse effects.

Specific drugs have been assessed. In one study transdermal buprenorphine was found to represent an efficient, safe and well tolerated approach to the management of children's chronic cancer pain. Eleven patients $(68.75 \%)$ responded to transdermal buprenorphine after 2 weeks of treatment. Pain intensity and all outcome measures of global quality of life, including quality of sleep, alimentation, play and activity, speech, and crying significantly improved over the 60-day study period. No severe adverse events were recorded [9]. Good analgesia with high level of satisfaction has been reported in 18 children treated with fentanyl given as patientcontrolled analgesia. All children experienced a good degree of analgesia and did not require any other analgesic drug during the treatment. Both subjective and objective parameters improved after starting pain-relieving treatment and no major side effects occurred [10]. In a multicenter study, transdermal fentanyl was found to be a safe and well tolerated alternative to oral opioid treatment. 132 cancer children from a sample of 173 with chronic pain who were previously exposed to opioid therapy were switched to transdermal fentanyl. Pain intensity scores and quality of life items improved, although about $80 \%$ of patients discontinued the treatment for a variety of reasons. The treatment for well-tolerated and serious adverse effects was reported in $9.5 \%$ of patients [11].

Two retrospective studies assessed the effects of opioid switching. In a series of seventeen patients switched to methadone, there was an improvement in analgesia with 16 patients remaining on methadone therapy until death for a median of 36 days [12]. Twenty-two children (14\%) on opioid therapy underwent 30 opioid rotations. The opioid was substituted either for excessive side effects or inadequate analgesia. Five patients (23\%) required two rotations, 3 during the same admission. Adverse opioid effects improved in $90 \%$ of cases, and all failures occurred when morphine was rotated to fentanyl. There was no significant loss of pain control or increase in mean morphine equivalent dose requirements [13].

One series reported about the effectiveness of ketamine in children receiving high doses of opioids. Subanesthetic doses of ketamine were used to treat 11 children who were on high doses of opioids and had uncontrolled cancer pain. In 8 of 11 patients, ketamine appeared to improve pain control and to have an opioid-sparing effect [14].

Data regarding interventional procedures were limited. One retrospective analysis of a small series assessed the use of epidural and peripheral nerve blocks in very advanced cancer children. Pain scores improved in nine cases in 1-5 days. A continuous catheter-delivered pain blockade contributed to analgesia, moderated opioid requirements, and did not preclude death at home [15].

\section{Discussion}

Despite increasing awareness about causes and treatment of pain in children, most of them with advanced illness still experience pain and receive suboptimal pain control [1]. The World Health Organization documents on cancer pain relief and palliative care in children has advocated the global application of the principles of pain management and palliative care for children with cancer. The principles of pain management include the application of the WHO analgesic ladder, appropriate opioid dose escalation, the use of adjuvant analgesics, and the use of non-pharmacological methods of pain control. These principles of pain management should be incorporated into the treatment protocols of all children with cancer, acknowledging that treatment options may be limited for some children [16]. However, regardless of general principles, clinical data should confirm the applicability of this concept and should suggest more specific recommendations particularly in more complex categories. At the moment there is no scientific evidence regarding the strategies to be used for 
Table 1

Trials on pharmacological management of cancer pain in children.

\begin{tabular}{|c|c|c|c|c|c|c|c|}
\hline Authors & No patients & Setting & Duration days & Drug and dose & Analgesic response & Notes & Tolerability \\
\hline Ruggiero et al. (2013) & 16 & Cancer pain & 60 & $\begin{array}{l}\text { Transdermal } \\
\text { buprenorphine } \\
8.75-35 \mu \mathrm{g} / \mathrm{h}\end{array}$ & $81.3 \%$ & $\begin{array}{l}\text { Better quality of } \\
\text { sleep, alimentation, } \\
\text { play and activity, } \\
\text { speech, and crying }\end{array}$ & $\begin{array}{l}\text { Good } 93.8 \% \text { Low } \\
\text { tolerance }\end{array}$ \\
\hline Geeta et al. (2010) & 39 & $\begin{array}{l}\text { Acute } \\
\text { leukemia }\end{array}$ & NA & WHO ladder & $\begin{array}{l}31 \% \text { on step } 1 \\
54 \% \text { on step } 2 \\
15 \% \text { on step } 3\end{array}$ & $\begin{array}{l}\text { Step } 3 \text { analgesia in } \\
\text { neuropathic and bone } \\
\text { pain. }\end{array}$ & Constipation \\
\hline Anghelescu et al. (2010) & $\begin{array}{l}14 \\
\text { retrospective }\end{array}$ & Cancer pain & $3-81$ & $\begin{array}{l}11 \text { epidural } \\
3 \text { nerve blocks }\end{array}$ & $\begin{array}{l}12 / 13 \text { evaluable } \\
\text { blocks improved pain } \\
\text { control }\end{array}$ & $\begin{array}{l}\text { No preclusion of } \\
\text { death at home }\end{array}$ & None \\
\hline Mishra et al. (2009) & 84 & Cancer pain & 3 weeks & WHO ladder & $\begin{array}{l}\text { Relevant decrease of } \\
\text { pain intensity, } \\
\text { independently of pain } \\
\text { mechanism }\end{array}$ & $\begin{array}{l}82 \% \text { on step } 3 \text { after } \\
\text { three weeks }\end{array}$ & $\begin{array}{l}\text { Acceptable number of } \\
\text { adverse effects }\end{array}$ \\
\hline Hewitt et al. (2008) & $\begin{array}{l}185 \\
\text { prospective }\end{array}$ & Cancer pain & Until death & WHO ladder & NA & $\begin{array}{l}\text { Strong opioids } 89 \% \text {, } \\
\text { Morphine } 75 \% \\
\text { Mean doses } \\
6.1-29.5 \mathrm{mg} / \mathrm{kg} \\
\text { Higher doses with } \\
\text { solid tumors }\end{array}$ & Nausea \\
\hline Davies et al. (2008) & $\begin{array}{l}17 \\
\text { retrospective }\end{array}$ & Cancer pain & $\begin{array}{l}\text { Until death } \\
\text { Median } 36 \\
\text { days }\end{array}$ & $\begin{array}{l}\text { Switched to } \\
\text { methadone }\end{array}$ & $\begin{array}{l}\text { Better pain control } \\
\text { ( } 94 \% \text { by parents) }\end{array}$ & $\begin{array}{l}\text { Starting dose } \\
0.1 \mathrm{mg} / \mathrm{kg}\end{array}$ & \\
\hline Zhen et al. (2007) & 139 & Cancer pain & NA & WHO ladder & $92.8 \%$ complete relief & $\begin{array}{l}74.8 \% \text { on step } 1 \\
25.2 \% \text { changing steps }\end{array}$ & $\begin{array}{l}\text { No severe adverse } \\
\text { events }\end{array}$ \\
\hline Ruggiero et al. (2007) & 18 & Cancer pain & $48 \mathrm{~h}$ & $\begin{array}{l}\text { Transdermal fentanyl } \\
1 \mu \mathrm{g} / \mathrm{kg} / \mathrm{h} \\
\text { PCA } 1 \mu \mathrm{g} / \mathrm{kg}\end{array}$ & $\begin{array}{l}\text { Good degree of } \\
\text { analgesia }\end{array}$ & $\begin{array}{l}\text { High grade of } \\
\text { satisfaction }\end{array}$ & $\begin{array}{l}\text { No major adverse } \\
\text { effects }\end{array}$ \\
\hline Finkel et al. (2007) & 11 & Cancer pain & $1-75$ days & $\begin{array}{l}\text { Ketamine } \\
0.1-1 \mathrm{mg} / \mathrm{kg} / \mathrm{h}\end{array}$ & $\begin{array}{l}8 / 11 \text { patients had a } \\
\text { good response }\end{array}$ & Opioid sparing effect & $\begin{array}{l}\text { No psychotropic } \\
\text { adverse effects }\end{array}$ \\
\hline Zernikov et al. (2006) & 124 & $\begin{array}{l}\text { Mostly pain } \\
\text { due to } \\
\text { treatment }\end{array}$ & $\begin{array}{l}2265 \\
\text { treatment days }\end{array}$ & WHO ladder & $\begin{array}{l}\text { Effective analgesia } \\
\text { with opioids }\end{array}$ & $\begin{array}{l}\text { The mean intravenous } \\
\text { morphine equivalence } \\
\text { dose was } \\
0.034 \mathrm{mg} / \mathrm{kg} / \mathrm{h} \text {. }\end{array}$ & $\begin{array}{l}\text { Adverse effects were } \\
\text { more frequent }\end{array}$ \\
\hline Finkel et al. (2005) & $\begin{array}{l}132 \\
\text { prospective }\end{array}$ & $\begin{array}{l}\text { Cancer pain } \\
\text { mostly } \\
\text { leukemia }\end{array}$ & 15 days & $\begin{array}{l}\text { Converted from } \\
\text { morphine to } \\
\text { transdermal fentanyl }\end{array}$ & $\begin{array}{l}86 \% \text { effective } \\
\text { analgesia } \\
\text { Reduction of rescue } \\
\text { medications }\end{array}$ & $\begin{array}{l}0.98 \mu \mathrm{g} / \mathrm{h} / \mathrm{kg} \text { to } \\
1.2 \mu \mathrm{g} / \mathrm{h} / \mathrm{kg} \text { data } \\
\text { mixed with } \\
\text { non-cancer population }\end{array}$ & $\begin{array}{l}3 \% \text { withdrawal for } \\
\text { adverse effects }\end{array}$ \\
\hline Monteiro-Caran et al. (2005) & 135 & Cancer pain & Mean 34 days & $\begin{array}{l}\text { WHO ladder } \\
\text { Strong opioids 23\% }\end{array}$ & $\begin{array}{l}\text { Satisfactory pain } \\
\text { control in } 97 \% \text { of } \\
\text { cases }\end{array}$ & $\begin{array}{l}\text { Initial dose of oral } \\
\text { morphine } 1.8 \mathrm{mg} / \mathrm{kg} \text {, } \\
\text { final dose } 7 \mathrm{mg} / \mathrm{kg}\end{array}$ & $\begin{array}{l}74 \% \text { adverse effects } \\
\text { Psychological } \\
\text { dependence in } 2 \% \text { of } \\
\text { patients }\end{array}$ \\
\hline Drake et al. (2004) & $21 \mathrm{pts}$ & Mucositis $70 \%$ & NA & $\begin{array}{l}\text { Opioid switching, } \\
\text { prevalently from } \\
\text { morphine to fentanyl }\end{array}$ & $\begin{array}{l}\text { No loss of analgesia, } \\
\text { without increasing } \\
\text { opioid doses }\end{array}$ & $\begin{array}{l}\text { Adverse effects } \\
\text { resolved in } 90 \% \text { of } \\
\text { cases }\end{array}$ & $\begin{array}{l}\text { Adverse effects } \\
\text { resolved in } 90 \% \text { of } \\
\text { cases }\end{array}$ \\
\hline
\end{tabular}


cancer pain management and recommendations are provided on limited experience, with limited number of drugs, reflecting only meaningful opinions of experts in the field. About ten years after a review on the management of cancer pain in children [2], the amount and the quality of data still remain poor, as less than 1000 thousand subjects (about 90 patients per year) were surveyed with open-label designs or retrospective analysis. Other than generic recommendations of WHO ladder, as in adults, it is likely that an individualized treatment may improve the outcome or reduce adverse affects. Of interest, no comparison among possible treatments or drugs has ever been done. Most of these trials are short-lived, or the duration of treatment not clearly explained, and assessment of adverse effects is often problematic. The experience with opioids is quite limited, and adjuvants have been seldom assessed, unless for case reports which have not been considered in this analysis. The management of breakthrough pain has never been specifically evaluated and only a study assessed the characteristics of this phenomenon in a small number of patients [17].

Other than the limited evidence of the existing recommendations, several practical points remain unclear and have clinical implications, due to unavailability of some preparations. For example, in pediatric hematology/oncology, pain control by oral long-acting morphine proved to be safe and effective even in the very young patients. The pharmacological properties of long-acting morphine are ideally suited for pediatric use, combining efficacy and compatibility [13], and initial doses of opioids have been suggested, based on the weight of children [11]. However, commercial preparations do not often fit the dose flexibility of opioids requested for children, particularly with slow release preparations or transdermal drugs. Only oral methadone and morphine can be provided as immediate release preparations which can be graduated in a syrup preparation, according to the weight. Alternately, parenteral morphine can be provided in precise doses. Similarly, transdermal opioids have been often reported as effective and non-invasive method for drug administration in children since it avoids discomfort due to intravascular or oral administration. Transdermal opioids represent a useful alternative, because low doses can be tailored according the needs just cutting the new matrix patch, as in most countries low dose strengths are unavailable [10].

Opioid switching may have a positive impact on managing dose-limiting side effects of, or tolerance to, opioid therapy during cancer pain treatment in children. In small retrospective series, this was accomplished without loss of pain control or having to significantly increase the dose of opioid therapy. Despite these encouraging data, this therapeutical approach remains limited to experienced people, due to the lack of prospective data.

Treatments alternative to opioids may be helpful in some circumstances of difficult pain. There are a number of small case series that suggest that ketamine is a useful medication for the control of chronic pain in children. To date, however, there are few data that aid a pediatrician in determining if ketamine is a safe and effective option for children with cancer pain, whose brains are immature and whose metabolism is different from that of adults [18]. Finally, data on invasive procedures remain anecdotal, and precise indications on who should receive such treatments, when these should be performed, and how these should be administered remain unclear.

\section{Conclusion}

The effective management of pain in pediatric patients with cancer has incalculable benefits to patients, their families, and physicians and nurses. While getting relief from pain for children with cancer may require not just adequate medication but also considerable patient and family education, the treatment with analgesic drugs remains the cornerstone of the therapy [19]. However, information regarding the pharmacological treatment of cancer pain in children is lacking. Further clinical trials are needed to evaluate dose equivalence, clinical efficacy and safety of opioid analgesics, differences in opioid response, adjuvants and other drugs commonly used to manage opioid-related adverse effects, and dose strengths necessary for most children. Unfortunately, the number of children with cancer pain is usually not large enough to support well controlled clinical trials at a single institution. Consequently, multicentre and perhaps multinational efforts are necessary to fully evaluate analgesic strategies for children with cancer pain.

\section{Conflict of interest}

No conflict of interest to be declared

\section{Reviewers}

Dr. Federica Aielli, Via Alba fucens 6, L'Aquila I-67100, Italy.

Dr. Sabine Kost-Byerly, Department of Anesthesiology/Critical Care Medicine, Charlotte Bloomberg Children's Center, Johns Hopkins University, Baltimore, MD 21287, United States.

Dr. Antonio Ruggiero, Pediatric Oncology Division, “A. Gemelli" Hospital, Catholic University of Rome, Largo A Gemelli, 1, I-00168 Rome, Italy.

Dr. Stefan J Friedrichsdorf, MD, Medical Director, Children's Hospitals and Clinics of Minnesota Pain Medicine, Palliative Care \& Integrative Medicine 2525 Chicago Avenue S, Minneapolis, MN 55404, United States.

\section{References}

[1] Hechler T, Ruhe AK, Schmidt P, et al. Inpatient-based intensive interdisciplinary pain treatment for highly impaired children 
with severe chronic pain: Randomized controlled trial of efficacy and economic effects. Pain 2013; September, http://dx.doi.org/ 10.1016/j.pain.2013.09.015. pii:S0304-3959(13)00512-5 [Epub ahead of print].

[2] Mercadante S. Cancer pain management in children. Palliat Med 2004; 18:654-62.

[3] Geeta MG, Geetha P, Ajithkumar VT, Krishnakumar P, Kumar KS, Mathews L. Management of pain in leukemic children using the WHO analgesic ladder. Indian J Pediatr 2010;77:665-8.

[4] Mishra S, Bhatnagar S, Singh M, et al. Pediatric cancer pain management at a regional cancer center: implementation of WHO Analgesic Ladder. Middle East J Anesthesiol 2009;20:239-44.

[5] Zhen ZJ, Sun XF, Xia Y, et al. Feasibility to treat pediatric cancer pain with analgesics for adults and their efficacy. Ai Zheng 2007;26:866-9.

[6] Monteiro Caran EM, Dias CG, Seber A, Petrilli AS. Clinical aspects and treatment of pain in children and adolescents with cancer. Pediatr Blood Cancer 2005;45:925-32.

[7] Zernikow B, Smale H, Michel E, Hasan C, Jorch N, Andler W. Paediatric cancer pain management using the WHO analgesic ladder-results of a prospective analysis from 2265 treatment days during a quality improvement study. Eur J Pain 2006;10:587-95.

[8] Hewitt M, Goldman A, Collins G, Childs M, Hain R. Opioid use in palliative care of children and young people with cancer. J Pediatr 2008;152:39-44

[9] Ruggiero A, Barone G, Liotti L, Chiaretti A, Lazzareschi I, Riccardi R. Safety and efficacy of fentanyl administered by patient controlled analgesia in children with cancer pain. Support Care Cancer 2007; 15:569-73.

[10] Ruggiero A, Coccia P, Arena R, et al. Efficacy and safety of transdermal buprenorphine in the management of children with cancer-related pain. Pediatr Blood Cancer 2013;60:433-7.

[11] Finkel JC, Finley A, Greco C, Weisman SJ, Zeltzer L. Transdermal fentanyl in the management of children with chronic sever pain. Cancer 2005; 104:2847-57.

[12] Davies D, De Vlaming D, Haines C. Methadone analgesia for children with advanced cancer. Pediatr Blood Cancer 2008;51:393-7.

[13] Drake R, Longworth J, Collins JJ. Opioid rotation in children with cancer. J Palliat Med 2004;7:419-22.

[14] Finkel JC, Pestieau SR, Quezado ZM. Ketamine as an adjuvant for treatment of cancer pain in children and adolescents. J Pain 2007;8:515-21.

[15] Anghelescu DL, Faughnan LG, baker JN, Yang J, Kane JR. Use of epidural and peripheral nerve blocks at the end of life in children abd young adults with cancer: the collaboration between a pain service and a palliative care service. Pediatr Anesth 2010;20:1070-7.

[16] Collins JJ. Cancer pain management in children. Eur J Pain 2001;5(Suppl. A):37-41.

[17] Friedtichsdrof S, Finney D, Bergin M, Stevens M, Collins J. Breakthrough pain in children with cancer. J Pain Symptom Manage 2007;34:209-16.

[18] Bradlau A, McDermott MP, Adams HR, et al. Oral ketamine for children with chronic pain. A pilot phase 1 study. J Pediatr 2013;163:194-200.

[19] Susman E. Cancer pain management guidelines issued for children; adult guidelines updated. J Natl Cancer Inst 2005;97:711-2.

\section{Biographies}

Sebastiano Mercadante achieved his doctor's degree with full marks in 1979. He specialized in anesthesiology (1980-1983) at University of Palermo; and in science of nutrition (1984-1987) at University of Palermo. He is Professor of Palliative Medicine, Postgraduate Master, University of Palermo, and Director of the Anesthesia and Intensive Care Unit, Pain Relief and Palliative Care Unit, La Maddalena Clinic for Cancer, Palermo, Italy. He has given more than 400 hundred lectures at national and international congresses, and is Associate Editor, on the editorial Board and/or referee of more than 30 international peer-reviewed journals in the field of pain and symptom management and anaesthesiology. He has published more than 400 papers in peer-reviewed international journals and is author of more than 40 chapters and books. He received the Umberto Veronesi award in 2003, Palermo, the award of excellence in scientific research, American Academy of Hospice and palliative medicine, Boston 2010, the award of the ESMO designed center of integrated oncology and palliative care, Stockolm 2011, and John Mendelsohn award, Houston 2013.

Antonino Giarratano achieved his doctor's degree in 1986 and specialized in Anesthesiology in 1989 at University of Palermo. He was assistant professor of anesthesiolgy and intensive care (2000-2005). Since 2005 he has been an associate professor of Anesthesiology and Chief of Intensive Care at University Hospital of Palermo. He is chairman of regional chapter of National Society of Anesthesiologists since 2003, and since 2005 member of the Italian Society of Anesthesiology and Critical Care Medicine and European Society (ESICM). Since 2004 he has been a Delegate Chief from Policlinico Health Management for "The Quality" of the Department of Anesthesiology, University of Palermo and associate researcher at the Biological and Molecular Department of National Council Research in Palermo. He has been the regional delegate for The Italian Society of Anesthesia and Intensive Care Medicine (2006-2009). Since 2011 he has been the Director of School of Anesthesiology and Intensive Care Medicine of University of Palermo. He has published a dozen papers in the field of intensive care, immunology, and coagulative disorders, and pain therapy. 